\title{
Empowerment Strategy of Village Enterprises Unit (VEU) to Improve Capacity and Their Performances in Sumedang Regency
}

\author{
Akadun $^{1}$, Hidayat ${ }^{2}$, Lalas Sulastri ${ }^{3}$
}

\begin{abstract}
.
The measurement of VEU performance was difficult because VEU was categorized as Medium, Small and Micro Enterprises (MSMEs). One of the characteristics of MSMEs was the absence of financial statements so that performance was difficult to measure. The VEU classification was very strategic in order to develop the capacity and performance of VEU. This study aims to develop a VEU empowerment strategy to increase capacity and performance Of VEU in Sumedang Regency. The study used data collection techniques in-depth interviews, observations, and documentation. Triangulation as a technical data analysis, data processing procedures included display data, data reduction, and drawing conclusions. The results showed that VEU performance was influenced by the legality and regulation of VEU governance; manager of entrepreneurial and dedication; mastered accounting and ICT; creating strong leadership; the type of VEU business to fulfill community needs; VEU governance of transparent, accountable, participatory, effective, efficient, and healthy (high liquidity, high profitability, high solvency). The VEU empowerment strategy is carried out by benchmarking, the internal quality assurance system, accreditation, the evaluation of outstanding VEU Managers, and VEU Achievement Assessment.
\end{abstract}

Key Words: governance, healthy, performace, accreditation.

\section{Introduction}

The Indonesian government provides village funds to improve the village economy. One of the development programs to improve the village economy is the development of VEU. In the implementation of the development of VEU in several regions the results have not been effective. For example, out of 270 villages in Sumedang Regency, about 85 villages have already established VEU (2018), which increased quite sharply in 2019 to $187 \mathrm{VEU}$. Of the $187 \mathrm{VEU}$, they have carried out new business activities. Twenty of the $55 \mathrm{VEUs}$ were able to run their business properly.

Moreover, the existence of the VEU has not had significant benefits to improve the welfare of the people directly (Sri Anggraeni, 2016). Yet according to research of Ridlwan, professional and ideal VEU activities can be part of efforts to improve local and regional economies in the scope of the national economy (Ridlwan, 2014). The general problems of VEU were revealed based on the results of the study of Zandri et al. (2018), such as finding the right program for the community, lack of public awareness, tourism destinations that were not yet known to the wider community, village market

1Public Administration, College of Administrative Science of Sebelas April Sumedang, West Java, Indonesia

2Public Administration, University of Nurtanio Bandung, West Java, Indonesia.

3Public Administration, College of Administrative Science of Sebelas April Sumedang, West Java, Indonesia. 
problems related to management, credit related problems, difficult access to processed marketing products, limited capital, VEU HR managers less competent, less effective programs. Community participation in the VEU was still lacking because the community's knowledge of the program was still small and contributed less to community empowerment due to VEU budget constraints (Prasetyo, 2016).

In order for the VEU to have an effective business, VEU empowerment was needed. The effectiveness of VEU empowerment was influenced by the VEU empowerment strategy. The VEU empowerment strategy relates to the characteristics of the VEU. In the Guidebook for the Establishment and Management of Bumdes, VEU had the main characteristics: (1) this body was owned by the village and managed together; (2) business capital originating from villages (51\%) and from the community (49\%) through equity participation (shares); (3) operationalization using business philosophy rooted in local culture; (4) the business sector carried out was based on the potential and results of market information; (5) the profits obtained were intended to improve the welfare of members (capital partners) and the community through village policy; (6) facilitated by the Government, Provincial Government, Regency Government, and Village Government; (7) the operationalization is jointly controlled (Village Government, Village Consultative Bodies, members of VEU) (Ridlwan, 2014, pg. 341).

The reality in Sumedang Regency was that most VEU had low performance and only a small proportion of VEU run their businesses. The reality of the VEU was due to various common problems faced by VEU such as institutions, management, and unprofessional human resource manager, especially the VEU leadership which was not yet strong. In addition, special problems were in accordance with the characteristics of each VEU.

In overcoming these problems, there are several strategies to empower VEU as small, micro and medium enterprises. According to Pramit Putri Oktavia in Rifa'i (2013), the small-medium industry empowerment strategy by The Office of Industry, Trade, and Cooperative of Banyuwangi Regency was based on internal resources owned to create core capabilities in achieving comparative advantage and competitive advantage of the products produced.

Shardow in Rifa'i (2013) explained that empowerment essentially discusses how individuals, groups and communities try to control their own lives and strive to shape the future according to their own desires. Sumodiningrat in Rifa'i (2013) said that community empowerment was pursued with economic development with the least effort to include financial assistance as venture capital, building infrastructure as a support for the development of activities, training for officials and the community and strengthening socio-economic institutions of the community.

The development strategy in Surya Sejahtera VEU, according to Adawiyah (2018) used a feedback survey strategy, education and training activities, team building, management activities, which were based on aspects of social capital in the form of participation, reciprocity, trust, social norms, honesty and action values proactive.

From several VEU empowerment strategies that had been carried out, they were unique for each VEU. Therefore, a VEU empowerment strategy is generally needed that can be used as a model for developing capacity and performance of VEU in Sumedang Regency (and even other Indonesian regencies and cities). Based on the background of the 
research, the purpose of this study was to develop a VEU empowerment strategy as a model for developing capacity and performance in Sumedang Regency.

\section{Empowernment}

Akadun (2005) said that empowerment as one of the control strategies changed the form of control from prescriptive (must be or should be) rules to values and shared visions and performance accountability. Shardow explained that empowerment essentially discusses how individuals, groups and communities tried to control their own lives and strived to shape the future according to their own desires (Rifa'i, 2013).

The conceptual foundation of empowerment in Indonesia was interpreted as guidance (Repelita VI document), participatory (empowerment of small industries in Bojonegoro Regency, Director General of Higher Education Malang), emancipatory (Empowerment of Small Business Women, Akatiga Bandung), Strengthening (Patterns of Development and Empowerment Strategy for Farmers as Movement Professional People's Economy), conditions and business climate (Potential for Cooperative Development in Sulawesi), Capacity building (Noor and Setyawati, 2010).

According to Akadun there are three approaches to change control as an empowerment effort, namely: (1) applying control strategies to organizational, process, and person strategies; (2) reduce or eliminate hierarchical management in the organization and encourage authority to the first or front lines; and (3) move the bureaucratic power out to the public. The VEU empowerment was an effort to move bureaucratic power out into the hands of the community (Akadun, 2005).

Empowerment is intended to improve the performance of VEU on an ongoing basis. VEU Performance Measurement will be more comprehensive when using balance scorecard performance measurements. More comprehensive, because the measurement of balance scorecard performance included financial performance and non-financial performance such as customer perspective, internal business, learning and growth (Ulya and Saraswati, 2015). However, this non-financial performance led to financial performance as well.

Financial performance was indicated by financial ratios, namely the comparison between institutional expenditure and the budget set multiplied by $100 \%$; efficient ratio was the comparison between expenditure to obtain income and realization of income multiplied by $100 \%$; the effectiveness ratio was a comparison between the realization of income and the income target set multiplied by 100\% (Ulya and Saraswati, 2015). Raden Rizki Nurhayati and Ersa Tri Wahyuni analyzed financial performance with capital structure indicators, productive asset quality, efficiency, liquidity and sustainable ratios (Susila, 2014).

The financial performance of a company was good if the company was healthy. The characteristics of a healthy company: (1) very concerned about income and expenditure. By emphasizing once expenditure, it is expected to generate maximum income; (2) able to fix the company's finances when the company's earnings decline; (3) companies were able to compete with other companies and always develop (https:/ / seventhsoft.net/analisa-laporan-keuangan-untuk-menilai-tingkat-kesehatansuatu-perusahaan/ downloaded on May 11, 2019). A healthy company if the company 
had high liquidity, high solvency, and high profitability (Rompas, 2013). Financial distress was a condition where the company's finances were in an unhealthy condition (Praptika and Rasmini, 2016).

Liquidity was the ability to fulfill its short-term obligations or debts to be paid with its current assets (Sari, 2013, Army, 2013). Liquidity ratio to measure the company's ability to fulfill short-term financial obligations based on working capital information on current assets and current debt (Reshita, 2015). A liquid company when the company was able to maintain a balance between income and expenditure so that the company could always fulfill its obligation to pay on time.

Solvability was a measure of a company's ability to fulfill all its obligations both short and long term (Rompas, 2013). This showed that the company had the ability to pay all existing debt obligations using the assets owned by the company. Solvability was a comparison between the amount of assets and the amount of loan capital so that it could be seen how much wealth the company had compared to all of its debts. Solvability or dept to total assets according to Yulianto was a term often used by companies to measure the company's ability to fulfill all financial obligations if the company was liquidated (Viandita et. al, 2013).

Rentability or profitability was an effort used to find out the company's ability to obtain profits, during a certain period it also provides an analysis of the level of management effectiveness in carrying out its operational activities (Sari, 2013). Profitability could be measured by comparing the profit minus tax with assets that can generate profits. Profitability was financial information used by investors in assessing company performance (Army, 2013). Rentability was a comparison between results and capital used to generate these results. We distinguished between the profitability of own capital and the profitability of the whole or the profitability of the company.

The VEU empowerment strategy is expected to increase the liquidity, solvency and profitability of VEU. The next implication of VEU empowerment is to improve the performance of VEU on an ongoing basis.

\section{Method}

Badan Usaba Milik Desa (Village Enterprises Unit) abbreviated as Bumdes (VEU) were business entities whose entire or part of their capital was owned by the Village through direct participation from separated Village assets in order to manage assets, services, and other businesses for the greatest welfare of the Village community (Minister Regulation of Village, Development of Disadvantaged Regions, and Transmigration Number 4 of 2015 concerning Establishment, Management, and Dissolution of VEU). In reality, not all villages are interested in establishing VEU, out of 270 villages in Sumedang Regency, only about 187 villages have established VEU. From around 187 VEU not all went well, only about 20 VEU were running their businesses smoothly. Therefore the research target was 20 of these VEU. The informant was the Head of the Community and Village Empowerment Service, the village head, and the VEU manager. Determination of targets and informants by purposive and snowball. Data collection used in-depth interviewing, observation, and documentation techniques. Data analysis 
using triangulation and Group Focus Discussion. Data processing procedures included displaying data, reducing data and drawing conclusions.

Research steps: (1) making interview guidelines, observation and documentation guidelines; (2) determination of objectives and informants purposively and snowball; (3) field research with in-depth interviews, observation and documentation studies; (4) triangulation analysis; (5) preparation of initial research reports; (6) FDG against the initial report; (7) improvement of the initial report into the final report of the study; (8) making articles for proceding international seminars and reputable journals.

\section{Result and Discussion}

\subsection{Conditions and Performance of VEU in Sumedang Regency}

Village Enterprises Unit as a unique business entity (business institutions owned by social-oriented public) still have quality objectives, namely production targets, rejecting product targets, sales targets, profit targets, customer satisfaction levels, economic impact targets on village economic growth, target benefit for the level the welfare of the villagers. On the other hand, VEU included Micro, Small and Medium Enterprises (MSMEs) so that it rarely made financial reports. However, to improve the health of VEU financial statements in the form of liquidity, solvency, and profitability were urgently needed. Sumedang Regency divided VEU into Basic VEU (Bumdes Dasar), Developing VEU (Bumdes Berkembang), and Autonomous VEU (Bumdes Mandiri). Basic VEU was VEU that already had many types of businesses and potential business, however, from the institutional, governance, and HR development sectors had not been good, the balance sheet does not yet exist, there were no financial reports. The developing VEU were VEU who already had a type of business and will develop other business units, had institutions (VEU development was included in the RPJMDes (Village Medium Term Development Plan), Village Regulations on VEU); Bylaw and Articles of Association of VEU; already had a sincere manager developing VEU, already had a sincere manager developing VEU, governance (strong leadership, accountable, transparent, participatory, effective and efficient), good HR development (improving manager competency). In addition, developing VEU had other characteristics, such as the existence of a simple accounting system (balance sheet) and periodic financial reports, including the existence of VEU liquidity already running but solvency, and low profitability. Autonomous VEU was a VEU that already has good business units, strong institutions, good VEU governance, periodic balance sheets and financial reports, and professional managers so that liquidity, solvency, and profitability were high.

Based on the categories and criteria as above, VEU in Sumedang Regency are generally Basic VEU, Developing VEU, only Berdikari VEU (Village of Citali) and Lugerta VEU (Ciuyah Villages) categorized as Autonomous VEU. The Berdikari VEU (Citali) and The Lugerta (Ciuyah) were actually very vulnerable to returning to being the Evolving VEU. The Berdikari VEU of Citali Village and Lugerta VEU of Ciuyah Village succeeded because of the Head of Visioner's Village Leadership in developing VEU capacity.

Strategic steps of the Village Head in developing VEU capacity. First, build leadership with a successful team in nominating the village head. Second, the commitment was manifested in the village leadership trident, namely the village head, the Chairperson of 
the Village Consultative Body (VCB), and VEU. Third, the development of VEU was a development program in the Village Medium Term Development Plan (RPJMDes). Fourth, it had a strong legal basis because of the existence of village regulations regarding VEU. Fifth, the synergy of village heads, community leaders, and the characteristics of the paternalistic community in developing VEU capacity. Sixth, determining the unit and type of business according to the village's potential and the needs of the village community. Seventh, good VEU governance because it was governed by good Articles of Association and Bylaws so strong leadership, VEU management oriented quality and community, coaching, continuous supervision and control, and periodic balance sheets and financial reports. Nevertheless, solvency and profitability were still low.

Basic VEU already had a type of business that benefits the community and had profits. Even some business units have been able to provide monthly salaries that are in accordance with the regency / city minimum wage. However, in fact these business units were generally controlled and managed by individuals. The management organization had not gone well-there was not even a manager yet. The implication was that VEU governance has not gone well. The balance sheet and financial statements had not yet been implemented (In some VEU that had not had large profits, the village government has important returns on capital, but for business units that have large profits, the business unit must deposit part of the funds into the village's original income according to the village head's agreement with business unit manager). Coaching, control and supervision were not going well.

The condition of the Basic VEU was because, first, the interests of the village government (especially the village head) were so strong that they allowed the absence of strong managers and poor governance of the village government. Secondly, there was a sense of reluctance in the village head in dealing with community leaders who remain serving as managers of VEU. Third, many community leaders want to be the managers of the VEU so that the one with the others drops each other or does not support each other.

Developing VEU already had several units and types of businesses that could meet community needs. VEU this category already had liquidity, solvency and profitability. However, VEU had small profits so that they were unable to provide decent compensation to managers (therefore the Developing VEU rarely had employees). The VEU manager was not a professional person but a sincere and sincere fighter developing VEU even though earning income far from the Regency/City minimum wage. The combatant's mentality from the manager made VEU run so that liquidity, solvency and profitability were smooth. This VEU also conducted bookkeeping and financial reports in a simple manner.

As part of MSMEs, the reality of the VEU was not much different from Mubyarto's opinion, some obstacles to community empowerment, especially MSMEs, could be seen from production, financing, human resources, marketing, partnerships, business management, and the government's role (Noor and Setyawati, 2010).

\subsection{Capacity Building in Improving VEU Performance}

Based on the existing conditions and performance of the VEU, the building of its capacity is different for each VEU category. Based on the field reality for the building 
of VEU capacity and performance, the categorization of VEU can be added by one more category, namely villages that do not have VEU.

The VEU capacity and performance development strategy is very dependent on the VEU category. The general strategy for capacity building of VEU conducted by the Sumedang Regency Government through the Community and Village Empowerment Service is: (1) the main VEU development with the establishment of Regent Regulations Number 22 Year 2018 concerning Technical Guidelines for the Establishment, Management and Dissolution of Village Enterprises Unit; (2) Dissemination and technical guidence of VEU; (3) establishment of the Forum Bumdes (VEU Forum).

However, for villages that did not have VEU, Basic VEU, and Developing VEU, the VEU capacity and performance development strategy will be more appropriate to use Benchmarking. Benchmarking by means of village heads and VEUs managers conducting comparative studies to healthy Autonomous VEU, both institutionally, governance and human resource development so that the VEU have high liquidity, solvency and profitability. The second way of Benchmarking is by gathering village heads who do not have VEU, the Village Head and VEU manager that includes Basics and Developing, then inviting village heads and managers who have succeeded in improving VEU' performance and telling success stories concerning healthy and improving VEU performance and what competencies are needed to improve health and improve the performance of VEU.

The strategy for capacity building to improve the performance of Developing VEU is by providing mentoring (accompaniment) so that it becomes Autonomous VEU. Mentoring to ensure VEU has strong institutions, good governance, and sustainable HR development. Capacity building strategies to improve the performance of Developing and Autonomous VEU in a sustainable manner is empowerment. The empowerment strategy aims to ensure that the performance improvement of Developing and Autonomous VEU are sustainable.

Outputs are expected to capacity building to improve VEU' performance, especially from the perspective of developing village head human resources, village officials, and VEU managers to improve the competency of village heads, village officials and VEU managers in good VEU governance. Competence, at least includes knowledge, attitudes, and skills.

The competencies that village heads and officials must have in developing VEU capacity and performance are: (1) Knowledge of: VEU capacity building strategies and programs with village medium-term development plans (RPJMDes); the significance of the legal basis for the development of VEU capacity and governance in the form of both village regulations and the statutes and by-laws of VEU; significance of collaboration and networking of village, VEU, and stakeholders; (2) attitude about: awareness to improve people's welfare through VEU, having a strong commitment to developing VEU capacity through capital participation and submission of village assets to VEU, commitment to work together and collaborating with various parties, being open, honest, fair and sincere in developing VEU (no personal interests); (3) communication skills, skills in designing VEU development, skills in collaborating and networking, skills in designing VEU village regulations and asset transfer, skills in convincing people to participate. 
The competencies that the VEU manager must have in developing VEU capacity and performance are: (1) Knowledge of: determining unit and type of business, Articles of Association/ statutes and Bylaws, governance (operations management, production management, marketing management, quality management) VEU, performance accountability (accounting, balance sheets and financial statements, management reports), information and communication technology; (2) Professional attitude, quality orientation, customer orientation, resilient, creative and innovative, open; (3) skills in making VEU Articles of Association / Bylaws, determining unit and type of business, governance, information and communication technology, making balance sheets and financial reports, management reports, making collaboration and networking.

\subsection{VEU Empowerment Strategy}

The empowerment strategy for Developing and Autonomous VEU were due to the reality that a program was often unsustainable when changing regimes or changing officials. Every new official must be creative. One form of creativity of the new official is the existence of a new development program. Officials excel when creative and have new programs. The jargon that officials only continue the old program is that the officials are not creative and do not achieve so closely in the Indonesian bureaucracy. Even though creating sustainable development, by strengthening and improving the performance of sustainable development programs is a certain achievement. Therefore, VEU empowerment was a strategy to strengthen and improve the performance of sustainable VEU. The VEU empowerment strategy was an integral part of the sustainable development model. Sustainable development of VEU both in terms of economic sustainability (profit), human social life, natural ecology (Rudi S. Rivai and Iwan S. Anugrah, 2011).

This empowerment strategy is directed to the Developing and Autonomous VEU. Through this strategy it is expected that there will be a continuous increase in the Developing VEU and Autonomous VEU. The Developing VEU Evolve into Autonomous VEU. Autonomous VEU are increasing in every dimension, both input such as institutions, capital and assets, HR quality, processes such as governance (business planning, unit and type of business, strong leadership, cooperation and collaboration, management reports, balance sheets and financial statements, guidance, control, and supervision), output (product quality, service quality, packaging quality), liquidity, solvency, profitability/ increase in profits and assets). The empowerment strategy to strengthen the quality of VEU is the selection of the Best (Champion) VEU and the selection of the Best (Champion) VEU (Champion) Managers. The selection of Champion of VEU and Managers is expected to maintain good VEU governance. However, in order to increase VEU performance on an ongoing basis, its empowerment strategy is through an internal quality assurance system and VEU accreditation. The VEU empowerment strategy, such as having a strong theoretical basis, as expressed by Ida Ruwaida Noor and Lugina Setyawati, the empowerment concept applied in studies had the same tendency, namely as an institutional strengthening and fostering of the MSME sector and includes six aspects: production, technology, marketing, managerial, capital and entrepreneurship. 


\section{Conclusion}

Based on its performance, the Sumedang Regency Government categorized VEU as Basic VEU, Developing VEU, and Autonomous VEU. In general, the VEU in Sumedang Regency include the Basic and Developing VEU, only the Berdikari VEU of Citali Village and Lugerta VEU of Ciuyah Village which could be categorized as Autonomous VEU. The capacity building model for improving performance of Basic VEU and Developing VEU can be in the form of benchmarking and mentoring, while capacity building to improve the performance of Developing and Autonomous can be in the form of empowerment. The Developing and Auonomous VEU empowerment strategy can be in the form of election of VEU and manager Champion (Achievement), internal quality assurance systems and VEU accreditation.

Increasing the performance of sustainable VEU is needed to erode the notion that the performance of an official when he is creative. Creative in the sense of producing new programs. In Indonesia, it is famous for the motto of changing officials, changing policies or changing programs. Motto like this sometimes makes development unsustainable. Even though the program should continue but its performance needs to be improved so that it continues to provide sustainable benefits to the community.

\section{References}

Adawiyah, R, (2018). Strategi Pengembangan Badan Usaha Milik Desa (Bumdes) Berbasis Modal Sosial (Studi Pada Bumdes Surya Sejahtera, Desa Kedungturi, Kecamatan Taman Kabupaten Sidoardjo), Tesis, Perpustakaan Universitas Airlangga.

Akadun (2005). Pemberdayaan Birokrasi Pemerintab: Upaya Peningkatan Kinerja Pelayanan Pemerintah Yang efektif, C.V. Maulana: Bandung.

Army, Juwita (2013). Pengaruh Leverage, Likuiditas, dan Profitabilitas Terhadap Risiko Sistematis Pada Perusahaan Perbankan Yang Terdaftar di BEI, Skripsi Program Studi Akuntansi Fakultas Ekonomi Universitas Padang.

Noor, Ida Ruwaida dan Lugina Setyawati, (2010). Pemberdayaan UKM: Catatan Reflektif Hasil Meta Riset, Jurnal Sosiologi Masyarakat, Vol. 15 No.1, Januar 2010: 39-50, Pusat Kajian Sosiologi, LabSosio FISIP-UI.

Pemerintah Republik Indonesia, Peraturan Menteri Desa, Pembangunan Daerah Tertinggal, dan Transmigrasi Nomor 4 Tahun 2015 tentang Pendirian, Pengelolaan dan Pembubaran Badan Usaha Milik Desa.

Peraturan Bupati Sumedang Nomor 22 Tahun 2018 tentang Petunjuk Teknis Pendirian, Pengelolaan, dan Pembubaran Badan Usaha Milik Desa.

Minister Regulation of Village, Development of Disadvantaged Regions, and Transmigration Number 4 of 2015 concerning Establishment, Management, Management and Dissolution of VEU

Prasetyo, Ratna Azis, (2016). Peranan Bumdes dalam Pembangunan dan Pemberdayaan Masyarakat di Desa Pejambon Kecamatan Sumberrejo Kabupaten Bojonegoro, Jurnal Dialektika, Volume XI Nomor 1 Maret 2016, 86-100.

Praptika, Putu Yulia Hartanti dan Ni Ketut Rasmini (2016). Pengaruh Audit Tenure, Pergantian Auditor dan Financial Distress Pada Audit Delay Pada Perusahaan Consumer Goods E-Jurnal Akuntansi Universitas Udayana Vol. 15 No. 3 Juni 2016; halaman 2052-2081, ISSN 2302-8556.

Reshita, Riries Mia, (2015). Pengaruh Promosi, Lokasi, dan Kualitas Pelayanan Terbadap Minat Menabung Nasabah di Bank BNI Sidoarjo, tesis STIE Perbanas Surabaya.

Ridlwan, Z, (2014), Urgensi Badan Usaha Milik Desa (Bumdes) Dalam Pembangunan Perekonomian Desa, Fiat Justisia: Jurnal Ilmu Hukum, Vol. 8. No. 3 Tahun 2014, pp. 424-440. 
Rifa'i, Bachtiar, (2013). Efektivitas Pemberdayaan Usaha Mikro, Kecil, dan Menengah (UMKM) Krupuk Ikan Dalam Program Pengembangan Masyarakat Desa Kedung Rejo Kecamatan Jabon Kabupaten Sidoardjo, Jurnal Kebijakan dan Manajemen Publik, Vol. 1 No. 1 Tahun 2013, pp. 130-136.

Rivai, Rudy S. dan Iwan S. Anugrah. (2011). Konsep dan Implementasi Pembangunan Pertanian Berkelanjutan di Indonesia, Forum Penelitian Agro Ekonomi Volume 29 No. 1, Juli 2011: hlm.13-24. Pusat Sosial Ekonomi dan Kebijakan Pertanian, IPB Bogor.

Rompas, Gisela Prisilia (2013). Likuiditas, Solvabilitas, Rentabilitas Terhadap Nilai Perusahaan BUMN Yang Terdaftar Di Bursa Effek Indonesia, Jurnal EMBA: Jurnal Riset Ekonomi, Manajemen, Bisnis, dan Akuntansi, Vol. 1 No. 3 Tahun 2013, hal. 252-262, ISSN 2303-1174, Fakultas Ekonomi dan Bisnis, Universitas Sam Ratulangi, Prodi Manajemen.

Sari, Yulimel (2013). Pengaruh Profitabilitas, Kecukupan Modal, dan Likuiditas terhadap Harga Saham, tesis Program Akuntansi Fakultas Ekonomi Universitas Negeri Padang.

Sri Anggraeni, Maria Rosa Ratna, (2016). Peranan Bumdes Pada Kesejahteraan Masyarakat Pedesaan Studi Pada Bumdes Di Gunung Kidul Yogyakarta, Modus, Vol. 28 (2), 155-167, 2016, ISSN 0852-1875.

Susila, Ahdiyat Agus, (2014). Strategi Kesuksesan Koperasi BMT Maslahah Dalam Pengembangan Usaha dan Pengelolaan Ekonomi Umat, Tesis Program Studi Hukum Islam Konsentrasi Keuangan dan Perbankan Syariah Program Pascasarjana Universitas Sunan Kalijaga, Yogyakarta,

Ulya, Eva Choirul dan Erwin Saraswati, (2015). Penerapan Balanced Scorecard Sebagai Tolok Ukur Dalam Pengukuran Kinerja (Studi Kasus Pada RSUD dr. Wahidin Sudiro Husodo Kota Mojokerto, Universitas Brawijaya Malang), http:// jimfe.ub.ac.id/index.php/jimfeb/article didownload 25 Maret 2016.

Viandita, Tamara Oca, Suhandak, dan Achmad Husaini (2013). Pengaruh Dept Ratio (DR), Price to Earning Ratio (PER), Earning Per Share (EPS), dan Size terhadap Harga Saham (Studi pada perusahaan Industri Yang Terdaftar di Bursa Efek Indonesia), Jurnal Administrasi Bisnis (JAB) Vol. 1 No. 2, April 2013, Universitas Brawijaya, 113-121.

Zandri, Latifvah Permata, Nurullatu Dika Novia Putri, Rizki Anfani Fahmi (2018). Strategi Pengembangan Badan Usaha Milik Desa (Bumdes) Dharma Utama, in Program Studi Keuangan Islam Fakultas Ilmu Agama Islam Universitas Islam Indonesia, Yogyakarta. https://dspace.uii.ac.id/handle/123456789/9816? show=full.

https://seventhsoft.net/analisa-laporan-keuangan-untuk-menilai-tingkat-kesehatan-suatu-perusahaan/ downloaded on May 11, 2019 